\title{
DYNAMICS OF PLASMA EXCITED BY THE PERIODIC SEQUENCE OF RELATIVISTIC ELECTRON BUNCHES
}

\author{
O.K. Vynnyk, I.O. Anisimov \\ Taras Shevchenko National University of Kyiv, Kyiv, Ukraine \\ E-mail: alexander.vynnyk@protonmail.com
}

\begin{abstract}
Wake wave excited by the resonant sequence of electron bunches grows to high amplitude after passage of several bunches. As electron bunches are injected into plasma at the same point, it results to high-amplitude plasma oscillations at the limited area in the plasma volume. Relaxation of the wake wave causes plasma heating via Landau damping. It moves to background plasma pressing-out from this area. So plasma density spatial distribution is disturbed. Such density profile deformation causes plasma frequency deviation, so that initial Cherenkov resonance is broken. Local plasma density decreases almost linearly with time. Front of the density perturbation has the shape similar to collision less shock wave.
\end{abstract}

PACS: 29.17.+w; 41.75.Lx

\section{INTRODUCTION}

Problem of the wake field excitation by the sequence of relativistic electron bunches is actual primary due to the problem of construction of new generation of accelerators with high acceleration rate [1].

Our previous article demonstrated that plasma heating via excited wake field moves to the restriction of the maximal magnitude of the wake wave [2]. Further study of this problem is given in this article. It is carried out using PIC simulation [3] via new code described in [4]. This code is optimized for beam-plasma interaction and takes into account the possible electronion collisions.

\section{MODEL DESCRIPTION AND SIMULATION PARAMETERS}

The simulation model was similar to [2], and close to previous plasma wake field acceleration experiments with the sequence of electron bunches [5], but performed using new PIC code [4] with improved particle advancer [6, 7], optimized geometry, 4 times better resolution $(512 \times 4096$ grid cells) and number of macro particles increased approximately by an order of magnitude.

The simulation geometry was axisymmetrical. Its size was $7.5 \cdot 60 \mathrm{~cm}$ with perfectly matched layers (PML) as walls of $0.4 \cdot 0.03$ corresponding geometrical dimension sizes. Large PML outer wall was required to extinguish reflected high-amplitude wake waves. Plasma was non-magnetized. Plasma was initially homogenous with density $1 \cdot 10^{17} \mathrm{~m}^{-3}$. Temperature was $1 \mathrm{eV}$ for electrons and $0.1 \mathrm{eV}$ for ions. Electron bunches of the initial length $0.56 \mathrm{~cm}$ and distance between bunches $9.14 \mathrm{~cm}$ were injected along the axis during the simulation time with resonant repetition frequency. Bunches density was $5 \cdot 10^{16} \mathrm{~m}^{-3}$ and their initial velocity was $2.8 \cdot 10^{8} \mathrm{~m} / \mathrm{s}$. Simulation time was $3 \cdot 10^{-8} \mathrm{~s}$ with time step $2 \cdot 10^{-13} s$ and 80 bunches injected.

\section{SIMULATION RESULTS FOR COLLISION LESS PLASMA}

\subsection{DYNAMICS OF ELECTRON BUNCHES}

At the initial stage almost uniform electron bunches' radial defocusing was observed (Fig. 1,a). Later nonuniform bunch deformation with intense defocusing at the near-axis bunch region and outer ring of high density was observed (Figs. 1,b-c). This non-uniform bunch defocusing correlates with the perturbation of the background plasma density profile.

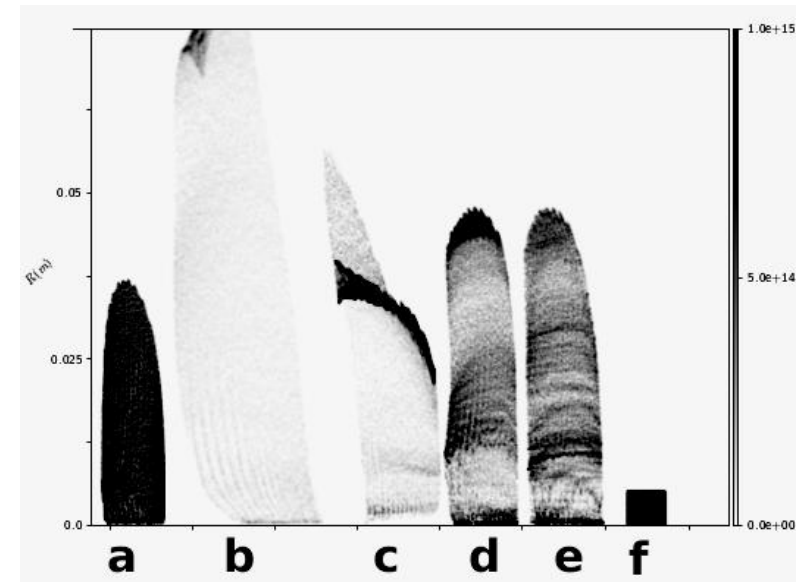

Fig. 1. Bunches at the different time points at the distance $0.3 m$ from the injection point: $a-1.1 \cdot 10^{-9} s ; b-4.9 \cdot 10^{-9} s ; c-8.9 \cdot 10^{-9} s$; $d-1.32 \cdot 10^{-8} s ; e-2.5 \cdot 10^{-8} s$; $f$-near the injection point

Increased spatial resolution, comparing to previous simulations [2,8], allowed observation of the highfrequency precursor ahead of electron bunches [9] 
(Figs. 2,3). Electric field of this precursor has mainly longitudinal component.

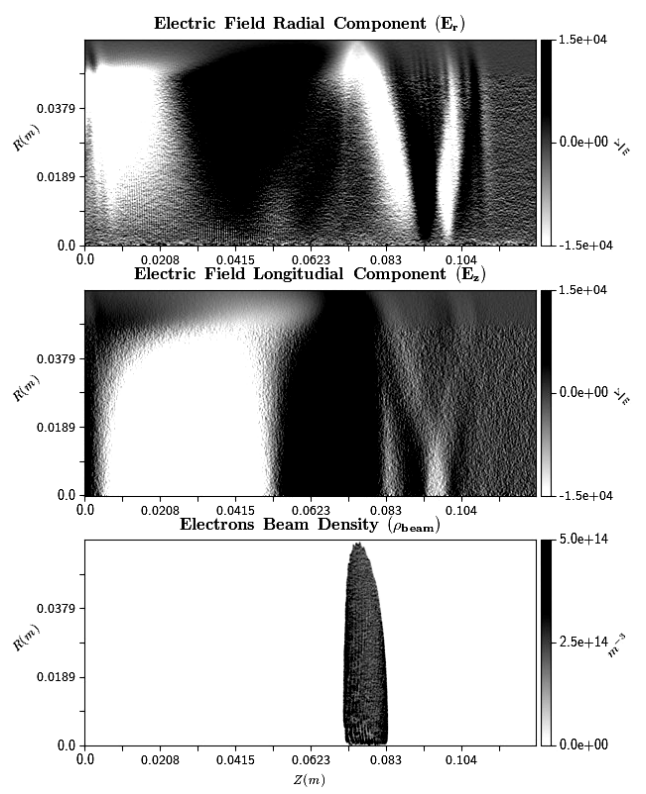

Fig. 2. Map of the electric fields and beam density. Precursor is placed above the main field perturbation

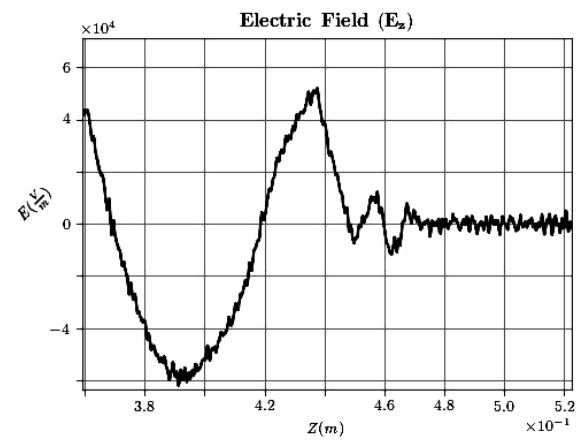

Fig. 3. Spatial plot of $E_{z}$ at the near-axis point. Precursor is at the right of the image

\subsection{WAKE FIELDS FORMATION}

The plasma wake wave is excited by the electron bunches at the initial stage of the simulation. Wake wave's amplitude growth is almost linear up to $5 \cdot 10^{-9} s$ (Fig. 4). Next stage corresponds to the interval $(5 \ldots 8) \cdot 10^{-9} s$. Wake wave's amplitude is saturated with further decreasing at this stage. Fig. 4 demonstrates temporal behavior of the excited wake field (normalized) at the point $r=1.5 \mathrm{~cm}, z=2.5 \mathrm{~cm}$ for the different time intervals. Oscillations at the Langmuir frequency of the unperturbed background plasma are also presented. One can see that at the time interval $(6.4 \ldots 8.9) \cdot 10^{-9} s$ the frequency exceeds the initial Langmuir frequency. At the interval $(13.2 \ldots 15.7) \cdot 10^{-9} s$ the inverse relation takes place.

This effect still needs further investigation. But it corresponds to the behavior of mean electron density (Fig. 5). Similar phenomenon was described in [10]. Authors unite it with the plasma electroneutrality failure according to the relation

$$
\omega_{p e}=\omega_{p 0}\left[1+\frac{1}{12} \ln \left(\frac{n_{e l}}{n_{i}}\right)\right] .
$$

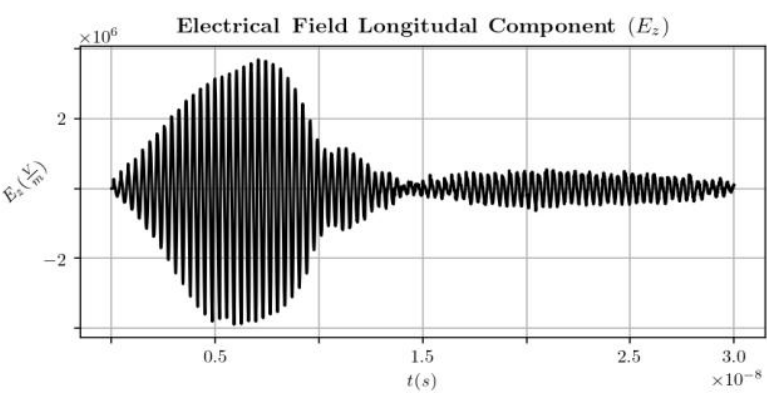

Fig. 4. Electric field temporal dynamics at the point $r=0.75 \mathrm{~cm}, z=2.5 \mathrm{~cm}$

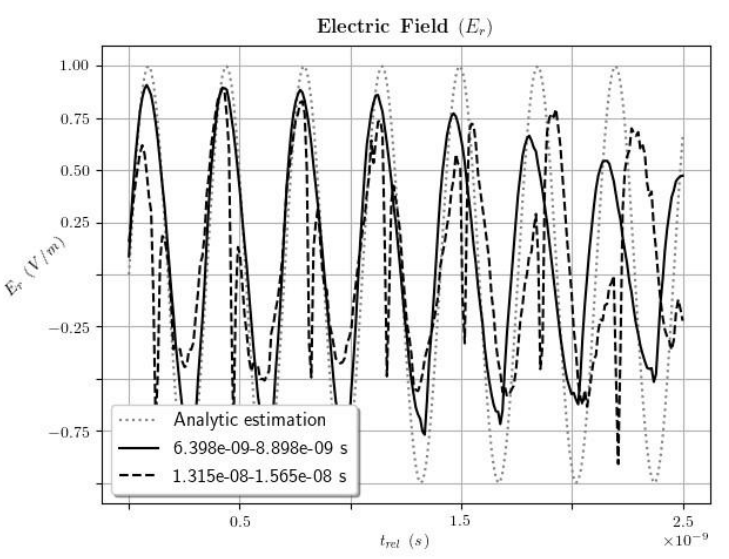

Fig. 5. Comparison of electric field frequencies for different simulation stages

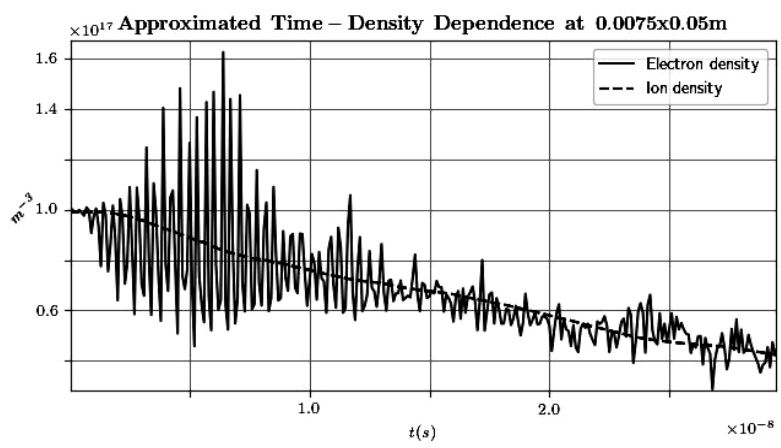

Fig. 6. Time dependence of electron and ion density near the injection point

Substitution of the simulation parameters gives $\Delta \omega_{\mathrm{pe}}<1 \%$ that is close to the observed frequency deviation.

Third stage continues from $8 \cdot 10^{-9}$ to $1.3 \cdot 10^{-8} \mathrm{~s}$. Wake wave's amplitude decreases to minimum caused by decreasing of plasma density (see Fig. 4).Plasma frequency also decreases to lower values (Fig. 6).

\subsection{PERTURBATION OF ELECTRON AND ION DENSITY PROFILES}

Starting from early time points, perturbation of plasma wake wave's front was observed. This effect was 
accompanied by the perturbation of electron and ion density at the same part of the simulation area. At the time points close to $10^{-8} s$ stationary decrease of electron and ion densities was observed at the near-axis region at the vicinity of the injection point $(0.5 \ldots 7 \mathrm{~cm}$ along $\mathrm{z}$ axis). At this time wake wave amplitude was saturated with further decrease. Time-density dependence at the point inside this region gives monotonic density decrease up to the end of the simulation $\left(3 \cdot 10^{-8} s\right)$ with several electron density fluctuations near the ion density plot (see Fig. 6).

Perturbation of the ion density radial profile at the late time points is similar tothe profile of the collision less shock wave (Fig. 7). Analytical estimations of the front width of such wave [9] give a value of the order of ion mean free path, $l_{\mathrm{fi}} \approx \mathrm{v}_{\mathrm{Ti}} \tau_{\mathrm{ii}}$, where $\mathrm{v}_{\mathrm{Ti}}$ is the ion thermal velocity, and $\tau_{\mathrm{ii}}$ is the mean time between ionion collisions. Estimations of the collision less shock wave front width for plasma parameters, used in simulation, give $l_{\mathrm{fi}} \approx 0.5 \mathrm{~cm}$ that is not far from the obtained values. Additional study of this effect is required.

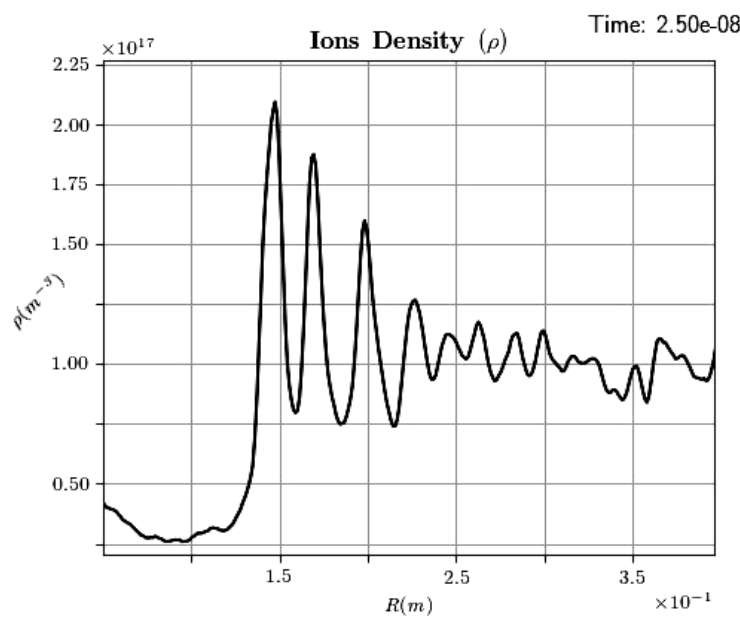

Fig. 7. Time-density dependence for electron and ion plasma component at near-injection point

\subsection{PLASMA HEATING BY THE WAKE FIELD}

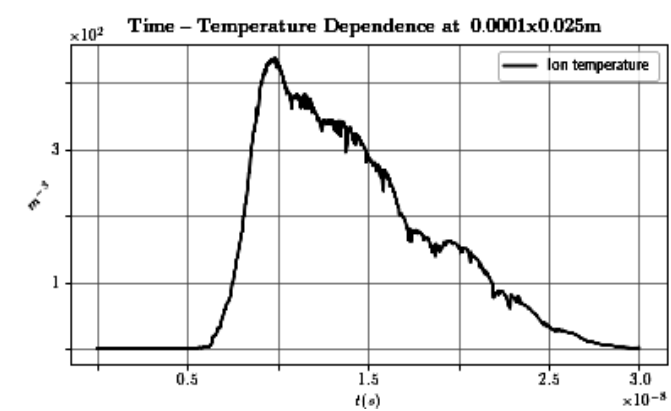

Fig. 8. Time-temperature dependence for ion plasma component at near-axis area near the injection point

There are two possible mechanisms of plasma heating by the charged particles' beams: heating by currents and Landau damping. The only mechanism of the collisionless plasma heating is Landau damping of the wake waves, excited by the charged particles bunches.

Substantial ion heating near the bunches` injection point was observed (Fig. 8). Later ion temperature is decreased. This effect can be united with the heated plasma expansion.

Note that start of substantial ions' heating coincides with the saturation of the wake wave amplitude (see Fig. 4).

\section{INFLUENCE OF WEAK PLASMA COLLISIONS}

Collisional simulation was performed to asses influence of direct coulomb collisions between particles to electron bunches and background plasma dynamics. Simulation was performed using improved classic PIC simulation scheme of Takizuka and Abe $[11,12]$ for binary coulomb collisions in plasmas. Simulation results gave almost the similar result without any significant differences - at least up to $10^{-8} \mathrm{~s}$.

\section{CONCLUSIONS}

Simulation carried out using new PIC code [4] confirms that plasma density perturbation at the trajectory of injected bunches move to the saturation of the wake field amplitude in this area and its further decrease. Electron density variation is non-monotonic in time. Precursor formed by preliminarily longitudinal electric field was observed before the first injected electron bunch. Ion density radial profile at the border of the reduced density area is similar to the collisionless shock wave.

\section{REFERENCES}

1. C. Blumenfeld, E. Clayton, et al. Energy doubling of $42 \mathrm{GeV}$ electrons in a metre-scale plasma wakefield accelerator // Nature. 2007, v. 445(7129), p. 741-744.

2. O. K. Vynnyk, I. O. Anisimov. Evolution of the wake wave excided by the sequence of the relativistic electron bunches // Problems of. Atomic Science and Technology. Series «Plasma Physics». 2019, № 4(122), p. 55-58.

3. C. K. Birdsall, A. B. Langdon. Plasma physics via computer simulation. New York: Taylor and Francis, 2005.

4. O.K. Vynnyk, I.O. Anisimov. PiCoPiC: 2.5-d particle-in-cell code, optimized for simulation of beamplasma interactions // Problems of Atomic Science and Technology. Series «Plasma Physics». 2020, № 6(130), p. 59-63.

5. V.A. Kiselev, A.F. Linnik, V.I. Mirny. Experiments on resonator concept of plasma wakefield accelerator driven by a train of relativistic electron bunches // Problems of Atomic Science and Technology. Series «Plasma Electronics and New Methods of Acceleration». 2008, № 4, p. 73-76. 
6. A.V. Higuera, J.R. Cary. Structure-preserving second-order integration of relativistic charged particle trajectories in electromagnetic fields // Physics of Plasmas. 2017, v. 24(5), p. 052104.

7. B. Ripperda, F. Bacchini, et al. A comprehensive comparison of relativistic particle integrators // The Astrophysical Journal Supplement Series. 2018, v. 235(1), p. 21.

8. O.K. Vynnyk, I.O. Anisimov. Wake wave excited by the sequence of relativistic electron bunches: Initial stage // Problems of Atomic Science and Technology. Series «Plasma Physics». 2018, № 6(118), p. 160-163.

9. S. Kumar Tiwari, A. Sen. Wakes and precursor soliton excitations by a moving charged object in a plasma // Physics of Plasmas. 2016, v. 23(2), p. 022301.
10. V. Osherovich, J. Fainberg. Dependence of frequency of nonlinear cold plasma cylindrical oscillations on electron density // Physics of Plasmas. 2004, v. 11(5), p. 2314-2317.

11. T. Takizuka, H. Abe. A binary collision model for plasma simulation with a particle code // Journal of Computational Physics. 1977, v. 25(3), p. 205-219.

12. F. Perez, L. Gremillet, et al. Improved modeling of ${ }^{\prime}$ relativistic collisions and collisional ionization in particle-in-cellcodes // Physics of Plasmas. 2012, v. 19, p. 083104.

\section{ДИНАМИКА ПЛАЗМЫ, ВОЗБУЖДЕННОЙ ПЕРИОДИЧЕСКОЙ ПОСЛЕДОВАТЕЛЬНОСТЬЮ РЕЛЯТИВИСТСКИХ ЭЛЕКТРОННЫХ СГУСТКОВ}

\section{А.К. Винник, И.А. Анисимов}

Кильватерная волна, возбужденная резонансной последовательностью электронных сгустков, увеличивается до больших амплитуд после прохождения нескольких сгустков. Так как электронные сгустки инжектируются в одной и той же точке, это приводит к высокоамплитудным плазмовым осцилляциям в ограниченной области плазменного объема. Релаксация кильватерной волны приводит к нагреванию фоновой плазмы по механизму затухания Ландау. Это приводит к выдавливанию фоновой плазмы с этой области. Таким образом, пространственное распределение плотности фоновой плазмы претерпевает возмущение. Такая деформация профиля плотности приводит к отклонению ленгмюровской частоты, поэтому начальный черенковский резонанс исчезает. Локальная плотность плазмы падает со временем почти линейно. Фронт возмущения плотности имеет форму, похожую на фронт ударной волны без столкновений.

\section{ДИНАМІКА ПЛАЗМИ, ЗБУДЖЕНОЇ ПЕРІОДИЧНОЮ ПОСЛІДОВНІСТЮ РЕЛЯТИВІСТСЬКИХ ЕЛЕКТРОННИХ ЗГУСТКІВ}

\section{О.К. Винник, І.О. Анісімов}

Кільватерна хвиля, збуджена резонансною послідовністю електронних згустків, зростає до великих амплітуд після проходження кількох згустків. Так як електронні згустки інжектуються в плазму в одній і тій же точці, це призводить до високоамплітудних плазмових осциляцій в обмеженій області плазмового об’єму. Релаксація кільватерної хвилі призводить до нагрівання фонової плазми за механізмом затухання Ландау. Це призводить до видавлювання фонової плазми з цієї області. Тож, просторовий розподіл густини плазми збурюється. Така деформація профілю густини призводить до відхилення ленгмюрівської частоти, тож початковий черенковський резонанс зникає. Локальна густина плазми спадає 3 часом майже лінійно. Фронт збурення густини має форму, схожу на фронт ударної хвилі без зіткнень. 